\title{
JUURNAL.RU
}

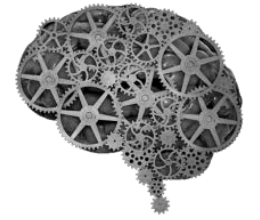

COMPANY GROUP "INTELLEKT"

Ромашкин Т.В. Национальный исследовательский Саратовский государственный университет им.

Н.Г. Чернышевского

Саратов, Россия

doi: 10.18411/lj2016-5-1-16

\section{Развитие корпоративной формы организации}

Институт корпорации в сложившейся кризисной ситуации является основополагающей силой, на которую делается ставка и правительством, и населением.

Как показывает мировой опыт, конкурентоспособность национальной экономики на мировых рынках напрямую зависит от успешной деятельности крупных корпораций, которые становятся самостоятельной силой глобального влияния.

Существуют различные концепции формирования и развития корпораций. Например, классическая концепция. Сущность этой концепции состоит в том, что корпорация рассматривается как общественный институт, профессиональное исторически сформировавшееся объединение со своим укладом жизни и своими законами. Суть этой модели в том, что предписания, отражающие взаимоотношения наёмного работника с работодателем, лишены юридического характера, а соответственно являются нечёткими. Лишь корпорация за счёт чёткой организации может создать условия для наиболее эффективного разделения труда. Далее следует выделить экономическую концепцию. Корпорация в данном случае понимается как надпрофессиональное объединение, для которого характерны общие цели, определенная иерархия и наличие внешних границ. Экономическая концепция изучает корпорации на 
трёх уровнях: отдельного рабочего корпорации, корпорации как организационной целостной структуры, корпорации как социального института. Корпорация, осуществляя связь своих интересов с обществом, становится ориентиром для индивидов. Рассматривая японскую концепцию, отметим, что эта концепция занимает место между экономической и классической концепциями, сочетая элементы организационной структуры и общинного начала. Японской концепции соответствует промежуточная модель, суть которой заключается в том, что корпорация должна формировать и совершенствовать навыки привыкания к различным моделям общества, учитывая при этом национальные особенности и многовековой опыт. Немаловажную роль играет и неоклассическая концепция. Следуя этой концепции, корпорация - это целостный объект, который в процессе производства преобразует исходные ресурсы в готовую продукцию. Таким образом, прибыль является главным критерием эффективности функционирования корпорации. На данный момент развивается институциональное направление и согласно ему, корпорация, это целостный экономический субъект, экономический интегратор, который объединяет различные социально-экономические процессы и обеспечивает безопасное и стабильное развитие. Современная концепция отличается от традиционных тем, что в традиционных концепциях корпорация аутентифицируется с производственной функцией, здесь же корпорация является объектом собственности, структурой управления. Организационная модель функционирования корпорации является контрактно-ориентированной, а в основе управления лежат горизонтальные связи. Также сторонники современной теории считают что, внутренние и внешние институты тесно взаимосвязаны, и правила, образуемые внешними институтами, являются основой для внутренних институтов. Приведённые концепции формирования и функционирования корпораций сменяли друг друга под влиянием следующих факторов: общественные потребности различались на разных исторических этапах 
развития общества; трансформировались культурные традиции; происходило дифференцирование уровней промышленного и экономического развития.

Отметим, что с точки зрения общефилософского подхода корпорация рассматривается как организм, то есть как организационная общность, представляющая собой систему согласованных и упорядоченных элементов. С точки зрения системного подхода корпорация рассматривается как машина, то есть как способ согласования взаимосвязей управляющей (аппарата управления) и управляемой подсистем (производственной структуры). С точки зрения социального подхода корпорация рассматривается как организация, то есть как социальная система, образованная для достижения общих целей. Но несмотря на многообразие подходов, они все же обладают общими принципами критериями рациональности формирования корпораций: единство выступает как формообразующий фактор; ориентация на достижение корпоративных целей; осуществление функций адаптации и социализации (гуманизация); формирование корпораций путём создания или реорганизации уже существующих корпораций (слияние, присоединение, преобразование, выделение, разделение); возможность оформления юридически (кроме профессионального сообщества - классической корпорации).

Основными характеристиками корпораций, являются следующие идеи: корпорация взаимосвязана с внешней средой; корпорация зависит от внутренних факторов; корпорация обладает выраженной общей целью; корпорация обладает определенным набором ресурсов, а также способов их защиты; корпорация функционирует по принципу синергизма, который основывается на том, что нечто целое наиболее эффективно, чем сумма его частей; корпорации присуща рациональная внутренняя организация; в структуре корпорации присутствуют органы, обеспечивающие контроль; корпорация является иерархической структурой (вертикальные связи); корпорация подразумевает наличие отделов и подразделений (горизонтальные связи); корпорации присущ индивидуализм и самостоятельность, например, при выборе контрагентов или организации 
производства; корпорации присущ прагматизм, то есть ориентация на прибыльность деятельности.

В последнее время среди крупных российских корпораций начинается активное обсуждение темы социальной ответственности бизнеса. Его инициаторами выступают профессиональные объединения предпринимателей [1, с. 173-175]. В области корпоративной социальной политики происходит реструктуризация деятельности органов управления в ряде корпораций. Появились корпоративные программы, предлагающие использовать новые социальные технологии.

Российский бизнес, с одной стороны, стремится выработать индивидуальные и общие подходы к социальной ответственности, внедрить международные принципы прозрачности, экологической безопасности, трудовых отношений, поддержки общества. С другой стороны, он вынужден содержать разваливающиеся социальные учреждения на территориях, сохранять большое количество «советских» льгот для персонала, оказывать помощь муниципалитетам в бюджетном планировании, испытывая при этом коррупционное давление со стороны органов власти. В этой ситуации выходом может являться разработка подходов к социальной ответственности компаний, основанных на общепринятых международных принципах социальной ответственности, в то же время предлагающих формы осуществления политики социальной ответственности с учетом особенностей России.

Корпоративная социальная ответственность бизнеса - это форма социального партнерства, добровольная обязанность бизнесменов проводить такую политику, принимать такие решения и следовать таким направлениям деятельности, которые желательны с точки зрения целей и ценностей общества. 


\section{Литература}

1. Ромашкин Т.В. Кластерная активность российского общества. В книге: Экономические, институциональные и технологические проблемы повышения конкурентоспособности национальной экономики в условиях внешних вызовов Материалы международной научно-практической конференции. Редакционная коллегия: Н.С. Яшин, Т.С. Мельникова, С.Ю. Седова, А.А. Сытник. 2015. С. 173-175. 